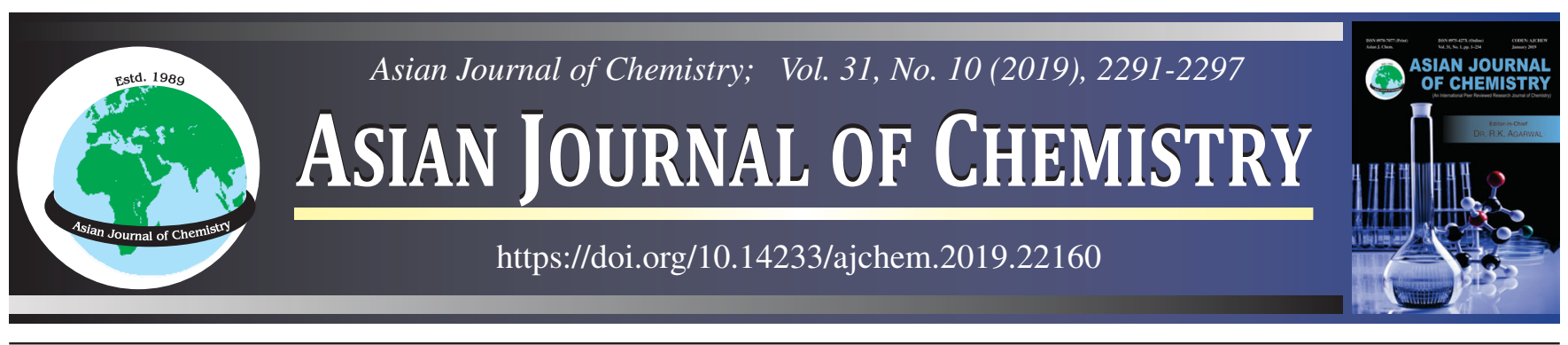

\title{
Removal of Rhodamine-B dye from Aqueous Solution using Biofertilizer containing Trichoderma viride as Low Cost Adsorbent
}

\author{
Kavita KulKarni ${ }^{*}$, , Anand Kulkarni and Poonam Bodare
}

Department of Chemical Engineering, Bharati Vidyapeeth (Deemed to be University), College of Engineering, Pune-411046, India

*Corresponding author: Tel/Fax: +91 20 24372998; E-mail: kskulkarni@bvucoep.edu.in; kavitashreya@gmail.com

Received: 28 April 2019;

Accepted: 30 May 2019;

Published online: 30 August 2019;

AJC-19538

\begin{abstract}
Trichoderma viride mixed with biofertilizer as low cost adsorbent was evaluated for the adsorptive removal of Rhodamine B dye from aqueous solution. To study the effect of contact period, $\mathrm{pH}$, agitation time, temperature, adsorbent amount and initial dye concentration batch adsorption experiment was performed. Kinetic study and adsorption isotherms were used to estimate experimental data and it was found that Freundlich isotherm model and kinetics of pseudo-second-order best fitted to the experimental data. The experimental results and separation factor $\mathrm{R}_{\mathrm{L}}$ concluded that Trichoderma viride present in biofertilizer can be used as an alternative to costly adsorbents for the removal of Rhodamine B from aqueous solution.
\end{abstract}

Keywords: Trichoderma viride, Biofertilizer, Rhodamine B, Adsorption.

\section{INTRODUCTION}

The remnant of textile world is one of the huge sources, which discharges huge amount of poisonous dye in the river [1]. Rhodamine B is used as a colouring agent in textile industry and food stuffs [2]. Rhodamine B dye has been reported as one of the most harmful compounds to sensitive living things than any other basic dyes [3]. Several physio-chemical methods are generally used to treat wastewater containing toxic dyes which includes membrane filtration, ozonation, precipitation, electro-flotation, irradiation and electrochemical destruction. However, all these methods are more expensive and cannot be applied by the small industries to treat huge amount of wastewater containing dye [4]. Between the possible techniques for water purification, the adsorption method by adsorbent shows more promising mechanism for the treatment and elimination of organic contamination in polluted wastewater. Adsorption has lead over other methods for the reason that easy design and can involve low investment interms of both initial required cost and land. In recent years, research for low cost agricultural adsorbents that have pollutant binding capacities has been intensified. Large scale available different natural material, agricultural and industrial wastes can be utilized as low cost adsorbents. Activated carbon has large surface area as itis extremely porous, which makes it and more effective adsorbent materials [4].

Adsorption of red colouring agent was done by coir pitch by varying the parameters. The adsorption capacity was found to be $6.72 \mathrm{mg} / \mathrm{g}$ [5]. Jackfruit peel waste was used as adsorbent for removal of rhodamine B dye. The monolayer removal of dye capacity was checked and found to be 4.361 to $1.98 \mathrm{mg} / \mathrm{g}$ [6]. The adsorption of rhodamine B dye, Congo red, procion orange was investigated by orange peel waste. The adsorption capacity was found 3.22, 1.2 and $22.4 \mathrm{mg} / \mathrm{g}$ for rhodamine B, Congo red and procion orange, respectively [7]. Sodium montomorillonite clay was also used for the adsorption removal of rhodamine $\mathrm{B}$ [8]. The biosorption capacity of $6 \mathrm{RG}$ on almond shell was investigated with respect to change in $\mathrm{pH}$, initial dye concentration, temperature and contact time. Dye removal capacity of almond shell powder was investigated to be 32.2 $\mathrm{mg} / \mathrm{g}$ [9]. Both orange and banana peel waste were shown to be promising low cost easily available adsorbent for the removal of dye from aqueous solution [10]. Adsorption removal of rhodamine $\mathrm{B}$ was also achieved by animal bone meal as low cost adsorbent [11]. The adsorption of rhodamine B dye was carried out by using agricultural waste rice husk based activated carbon [12]. Humic acid modifying $\mathrm{Fe}_{3} \mathrm{O}_{4}$ was developed for

This is an open access journal, and articles are distributed under the terms of the Attribution 4.0 International (CC BY 4.0) License. This license lets others distribute, remix, tweak, and build upon your work, even commercially, as long as they credit the author for the original creation. You must give appropriate credit, provide a link to the license, and indicate if changes were made. 
removal of rhodamine B. At optimized $\mathrm{pH} 98.5 \%$ removal was obtained for rhodamine B in water [13]. Chemically modified walnut shell was investigated for the removal of reactive brilliant red dye [14]. The removal of methylene blue dye from aqueous solution by tea wastes was investigated and the removal capacity of dye was found to be $461 \mathrm{mg} / \mathrm{g}$ [15].

Trichoderma viride plus compasses of enormous a fungal strain which stays in the plant roots and induce growth of plant [16]. Biofertilizers can be used to remove pollutant like fluoride from the water [17]. It is also used to control the diseases in plant. It also does the work of soil conditioning and increases helpful microorganism for the plant. The aim of present experiment is to study the mechanism of adsorption of rhodamine B dye using biofertilizer containing Trichoderma viride. Feasibility of using this biofertilizer as low cost biosorbent for the removal of toxic rhodamine B dye was studied. The effect of temperature, contact time, initial dye concentration, $\mathrm{pH}$ and rpm was investigated. The thermodynamic, kinetic and equilibrium parameters are studied.

\section{EXPERIMENTAL}

Adsorbent characterization: Biofertilizer containing Trichoderma viride was purchased from Mahatma Phule Krushi Vidyalaya Agricultural College, Rahuri, India. Adsorbent was washed and dried before being used.To study the morphology and elemental analysis, scanning electron microscopy and electron dispersive spectroscopy analysis was performed for adsorbent.

Adsorbate: All required chemicals were of AR grade and purchased it from a nearby chemical agency, Pune, India. Rhodamine B (1 g, AR grade) was dissolved in $1000 \mathrm{~mL}$ double distilled water and used as stock solution for the experiments. Desired dilution was done for the required concentration of dye solution.

Batch adsorption: A horizontal shaker was used for experiments. For each experiment, $100 \mathrm{~mL}$ of rhodamine B dye solution having different concentration of dye viz. 7, 10, 15, 18, $20 \mathrm{mg} / \mathrm{L}$ was taken in $250 \mathrm{~mL}$ stopper conical flask. The adsorbent dose was optimized for different amount of bioadsorbents. The effect of temperature and rotation for the removal of rhodamine B were also studied at different temperatures $(40,45,50,55$ and $\left.60^{\circ} \mathrm{C}\right)$ and rotations (120, 140, 160, 180 and $\left.200 \mathrm{rpm}\right)$.

Optimized contact time was also determined for studying dye removal capacity of biofertilizer from water. Equilibrium was attained at $120 \mathrm{~min}$ for biofertilizer containing Trichoderma viride. Effect of $\mathrm{pH}$ was conducted by calibrating $\mathrm{pH}$ with 0.1 $\mathrm{N} \mathrm{HCl}$ and $0.1 \mathrm{~N} \mathrm{NaOH}$ using Elico LI-120 pH meter, keeping constant dye concentration $20 \mathrm{mg} / \mathrm{L}$ for biofertilizer containing Trichoderma viride and the optimized parameters were adsorbent $2 \mathrm{~g}$, temperature $50^{\circ} \mathrm{C}$ and contact time $120 \mathrm{~min}$. After saturation, the filtrate was analyzed for concentration of dye $20 \mathrm{mg} / \mathrm{L}$. The residual concentration of rhodamine B dye was analyzed by using UV Spectrophotometer (Lab India Analytical UV 3000+Model). Using wavelength at $\lambda=523$ $\mathrm{nm}$, the dye solution calibration was carried out for both concentration as well as the absorbance.

The removal of dye in terms of percentage removal capacity was calculated as follows:

$$
\text { Removal }(\%)=\frac{\mathrm{C}_{\mathrm{o}}-\mathrm{C}_{\mathrm{e}}}{\mathrm{C}_{\mathrm{o}}} \times 100
$$

where $C_{0}=$ initial concentration of dye solution $(20 \mathrm{mg} / \mathrm{L}) ; \mathrm{C}_{\mathrm{e}}$ $=$ equilibrium concentration of dye solution.

The fraction rhodamine $\mathrm{B}$ dye adsorbed per $\mathrm{mg}$ of adsorbent is given as:

$$
\mathrm{q}=\frac{\left(\mathrm{C}_{\mathrm{o}}-\mathrm{C}_{\mathrm{e}}\right) \mathrm{V}}{\mathrm{M}}
$$

where $\mathrm{q}=$ amount of dye adsorbed per $\mathrm{mg}$ of adsorbent $(\mathrm{mg} / \mathrm{g})$; $\mathrm{V}=$ volume takenof dye solution $(\mathrm{L})$, and $\mathrm{m}=$ mass of biosorbent used $(\mathrm{g})$.

\section{RESULTS AND DISCUSSION}

SEM analysis: Micrographical structure of biofertilizer containing Trichoderma viride was seen by scanning electron microscopy, where porous and layered structure was observed (Fig. 1). Elemental analysis showed carbon and oxygen are the major source for microorganisms (Table-1).

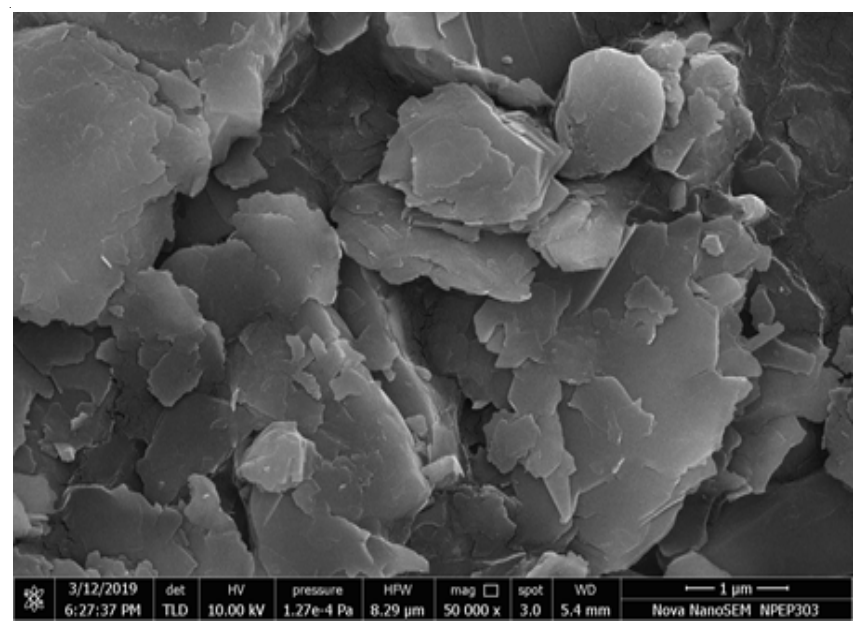

Fig. 1. Scanning electron microscopy of trichoderma plus biofertilizer

\begin{tabular}{cc|cc}
\multicolumn{4}{c}{ TABLE-1 } \\
\multicolumn{4}{c}{$\begin{array}{c}\text { ELEMENTAL ANALYSIS TRICHODERMA } \\
\text { PLUS BIOFERTILIZER }\end{array}$} \\
\hline Element & Wt. \% & Element & Wt. \% \\
\hline $\mathrm{C}$ & 32.04 & $\mathrm{Ca}$ & 1.27 \\
$\mathrm{O}$ & 44.99 & $\mathrm{~N}$ & 0.93 \\
$\mathrm{Si}$ & 10.30 & $\mathrm{Mg}$ & 5.15 \\
$\mathrm{Al}$ & 2.43 & $\mathrm{P}$ & 0.06 \\
\hline
\end{tabular}

FT-IR analysis: Fig. 2 represents FTIR spectra of biofertilizer containing Trichoderma viride in its powdered form. The peak appeared at $1000 \mathrm{~cm}^{-1}$ displays C-O stretching. At $1500 \mathrm{~cm}^{-1}$ wave numbers peak represents $-\mathrm{C}-\mathrm{C}$ - stretching of alkane group. The peak value at $2800 \mathrm{~cm}^{-1}$ represents the $\mathrm{C}-\mathrm{H}$ stretching group of alkane. The bands at 2500 and $2800 \mathrm{~cm}^{-1}$ indicates the presence of carboxyl functional groups. The peak at $3400 \mathrm{~cm}^{-1}$ represents hydroxyl compound and $3675 \mathrm{~cm}^{-1}$ corrosponds to the amide group.

Effect of contact time and initial concentration: The effect of contact period on dye removal capacity is shown in Fig. 3 for biofertilizer containing Trichoderma viride. The erad- 


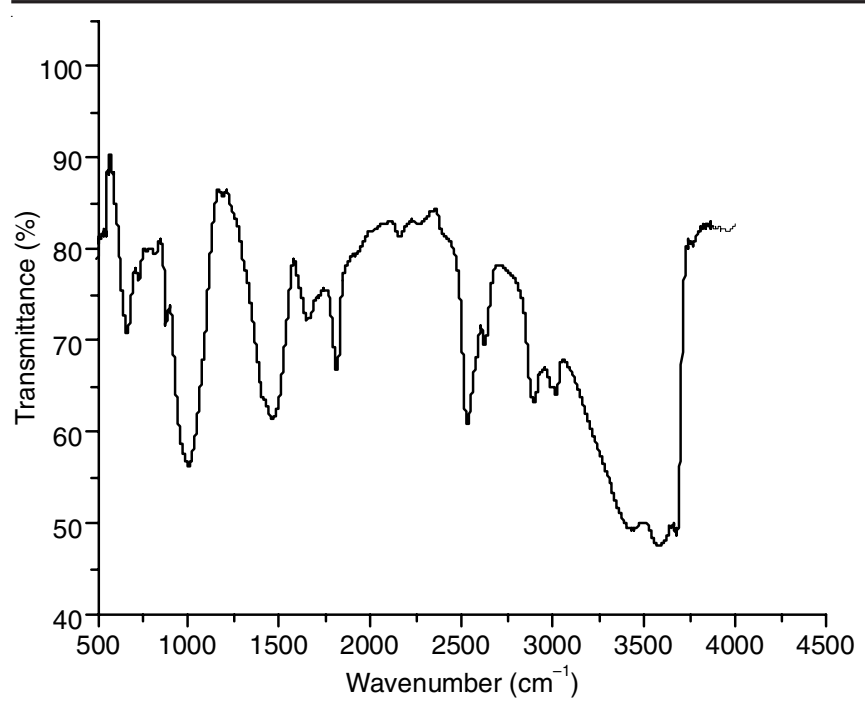

Fig. 2. Fourier-transform infrared spectroscopyof trichoderma plus biofertilizer

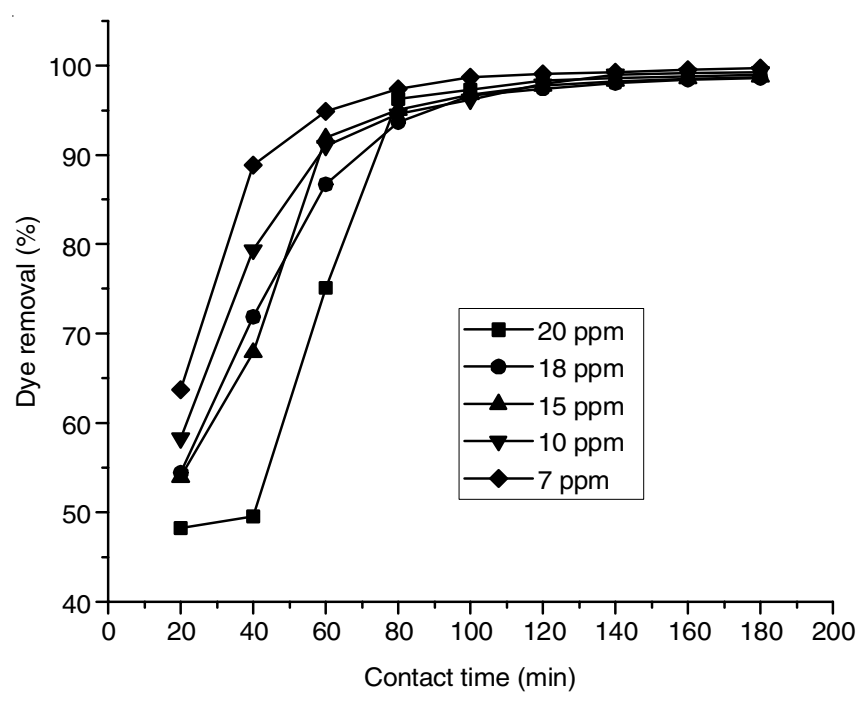

Fig. 3. Effect of time of contact and initial concentration on removal of dye

ication capacity was more for first $20 \mathrm{~min}$ and achieved maximum removal capacity after $120 \mathrm{~min}$ for biofertilizer containing Trichoderma viride and thereafter became stagnant. Removal of dye capacity exhibited a decreasing manner when the aqueous dye concentration was raised from 7 to $18 \mathrm{mg} / \mathrm{L}$. The percentage removal was decreased with increased dye concentration (78 to $58 \%$ ). Fast removal of dye during first 20 min may be the result of the perforation of positively charged ions within the surface of the adsorbent containing very small pores. The rate of removal was slowed after $100 \mathrm{~min}$ and after $120 \mathrm{~min}$ saturation was achieved.

Effect of pH: The pH of the dye varied from 5 to 9 to know the removal capacity of adsorbent. At pH 5, the adsorbent capacity for removal of dye was highest (Fig. 4). It was observed that low $\mathrm{pH}$ supported the adsorption process as compared to higher $\mathrm{pH}$. The removal efficiency at acidic surface is large means the surface of biofertilizer containing Trichoderma viride may be anionic and attracts rhodamine $\mathrm{B}$ molecules (cationic) or may be in the presence of acidic medium, the microorganisms present on the adsorbent gets activated and the dye removal was maximum at low $\mathrm{pH}$.

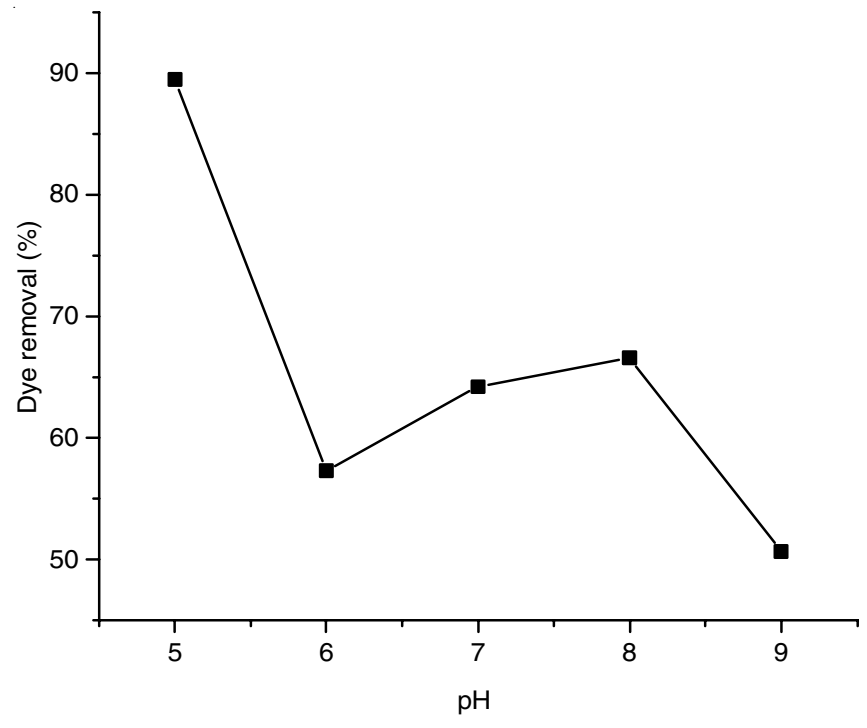

Fig. 4. Effect of $\mathrm{pH}$ on removal efficiency of dye

Effect of adsorbent dose: Adsorbent dose varied in the range of 1.0 to $3.5 \mathrm{~g}$. The removal percentage of rhodamine $\mathrm{B}$ dye increased as the adsorbent dosage increased. The removal of dye was increased from 27 to $48 \%$ due to the availability of more adsorption site so increased the possibility of more adsorption (Fig. 5).

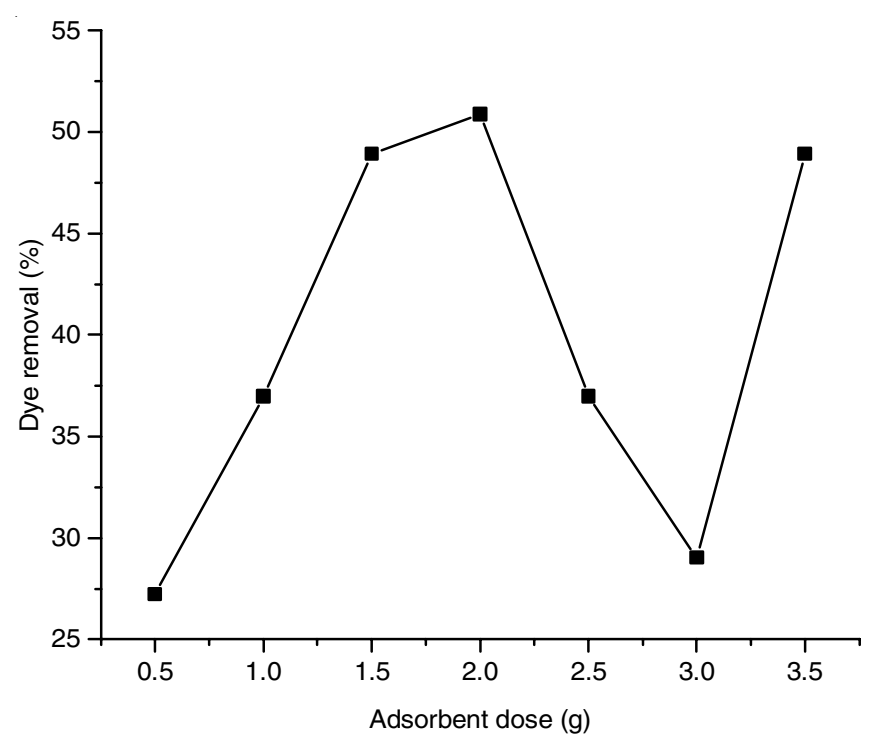

Fig. 5. Effect of adsorbent dose on removal efficiency of dye

Effect of temperature: If the adsorption increases with increase in temperature then it is endothermic adsorption. This may be due to the increase in the movement of dye molecules and an increase in the number of the active sites of adsorbent with increase in temperature. The highest removal of dye was occured at $50^{\circ} \mathrm{C}$ for biofertilizer containing Trichoderma viride (Fig. 6).

Effect of rotation per minute: Five different rotation per minute (rpm) in the range of 120-200 was used for conducting the experiment to study the rpm effect on adsorption. Increase in rpm resulted in increase in the dye removal efficiency (Fig. 7). Decrease in the resistance to the boundary layer was observed when rpm was increased and this was helpful for transfer 


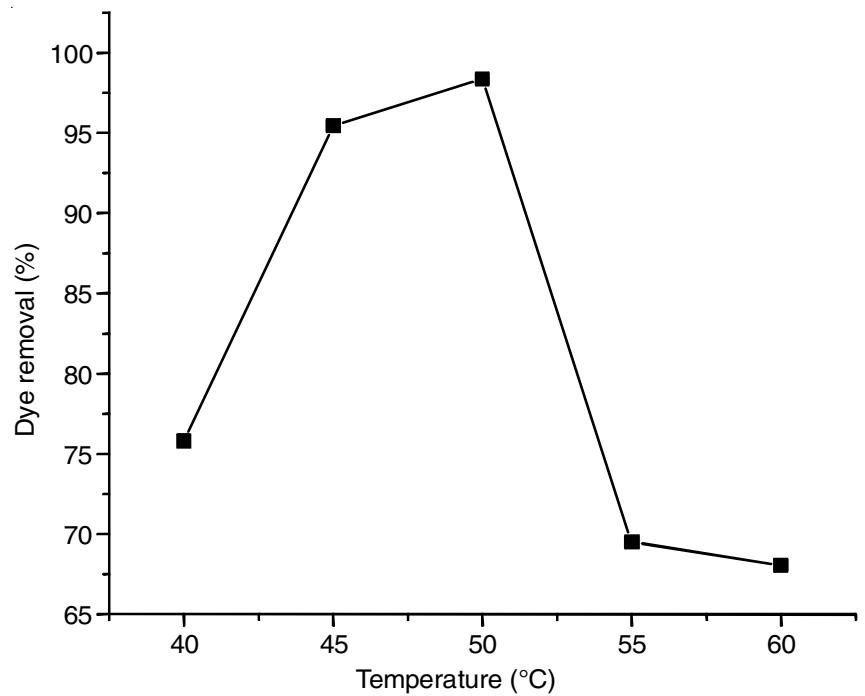

Fig. 6. Effect of temperature on removal of dye

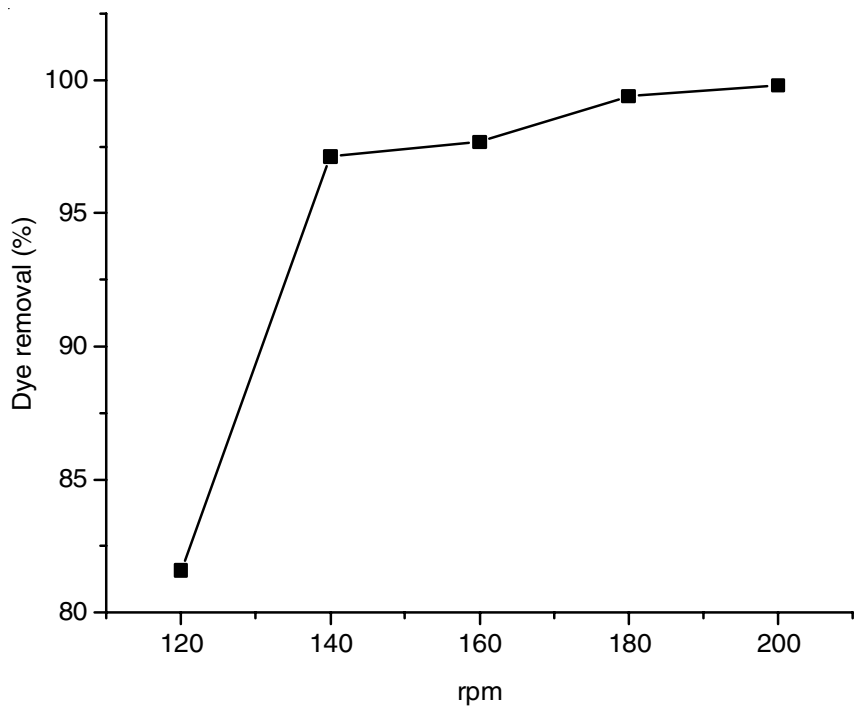

Fig. 7. Rotation per minute (rpm) effect on trichoderma plus biofertilizer

of the adsorbate molecule from the bulk of the solution to surface of the adsorbent. Due to this, the adsorbate is forced towards the adsorbent surface which increase the adsorbentadsorbate reaction resulting increasing the dye removal capacity of both adsorbents at $200 \mathrm{rpm}$.

Adsorption isotherms: Three isotherm model have been used to analyze the experimental data (i) Langmuir isotherm, (ii) Freundlich isotherm, and (iii) Temkin isotherm.

Langmuir isotherm can be defined as follows:

$$
\frac{\mathrm{C}_{\mathrm{e}}}{\mathrm{q}_{\mathrm{e}}}=\frac{1}{\mathrm{~K}_{\mathrm{L}}}+\frac{\mathrm{a}_{\mathrm{L}}}{\mathrm{K}_{\mathrm{L}}} \mathrm{C}_{\mathrm{e}}
$$

where $\mathrm{C}_{\mathrm{e}}=$ equilibrium concentration, $\mathrm{q}_{\mathrm{e}}=$ number of moles adsorbed at equilibrium; $\mathrm{K}_{\mathrm{L}}=$ Langmuir constants; $\mathrm{a}_{\mathrm{L}} / \mathrm{K}_{\mathrm{L}}$ gives the maximum adsorption capacity. Fig. 8 represents the Langmuir adsorption plot for adsorption of rhodamine $\mathrm{B}$ dye. The correlation coefficient for the Langmuir isotherm was found to be 0.563 .

The separation factor $\mathrm{R}_{\mathrm{L}}$ is another important parameter which decides the favorability of the process.

$$
\mathrm{R}_{\mathrm{L}}=\frac{1}{1+\mathrm{a}_{\mathrm{L}} \mathrm{C}_{\mathrm{o}}}
$$

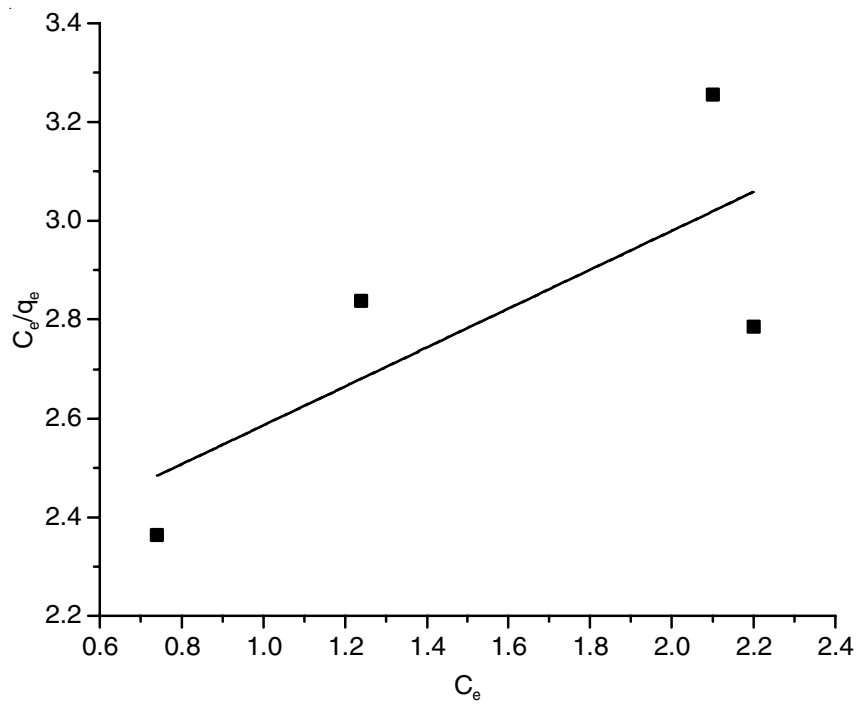

Fig. 8. Langmuir plot for dye adsorption on trichoderma plus biofertilizer

when $R_{L}$ is zero then the adsorption is irreversible while $0<$ $\mathrm{R}_{\mathrm{L}}<1$ denotes the favourable adsorption process and $\mathrm{R}_{\mathrm{L}}>1$ no adsorption is observed. $\mathrm{R}_{\mathrm{L}}$ value for the adsorption of dye was found to be 0.078 showed that the adsorption is favourable.

Freundlich constant can be defined as follows:

$$
\log \mathrm{q}_{\mathrm{e}}=\log \mathrm{k}_{\mathrm{f}}+\frac{1}{\mathrm{n}} \log \mathrm{C}_{\mathrm{e}}
$$

where $\mathrm{C}_{\mathrm{e}}$ and $\mathrm{q}_{\mathrm{e}}$ are the values at equilibrium, $\mathrm{k}_{\mathrm{f}}$ is the Freundlich constant, and $1 / \mathrm{n}$ is the factor of heterogeneity. For Freundlich model, the adsorption process by biofertilizer containing Trichoderma viride as the correlation coefficient was found to be 0.966 (Fig. 9).

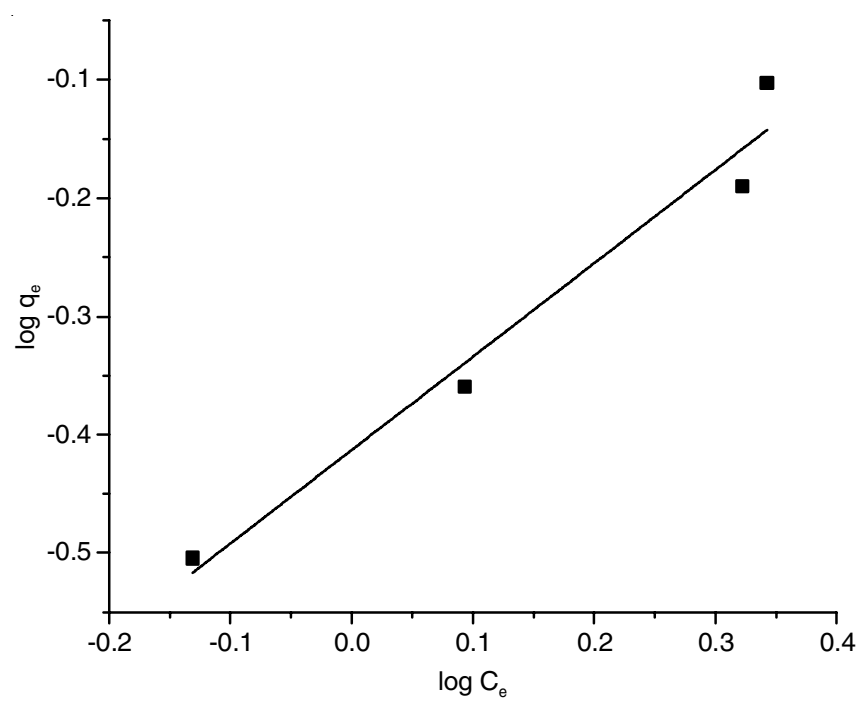

Fig. 9. Freundlich plot for trichoderma plus biofertilizer

Temkin isotherm: The equation of Temkin isotherm indicates a linear decrease in sorption energy as the degree of fulfilment of the area of sorption of a bioadsorbent is raised. This model gives the information about adsorbate/adsorbent interaction and implies that because of this intermolecular reaction adsorption heat of all molecules would decreases linearly. The Temkin isotherm is represented as follows: 


$$
\mathrm{q}_{\mathrm{e}}=\mathrm{B}_{1} \ln \mathrm{K}_{\mathrm{T}}+\mathrm{B}_{1} \ln \mathrm{C}_{\mathrm{e}}
$$

The correlation coefficient for the adsorption process of dye was found to be 0.725 (Fig. 10). As compared to Langmuir isotherm, this model was found to be suitable for the process. The other statistical and isotherms parameters are tabulated in Table-2.

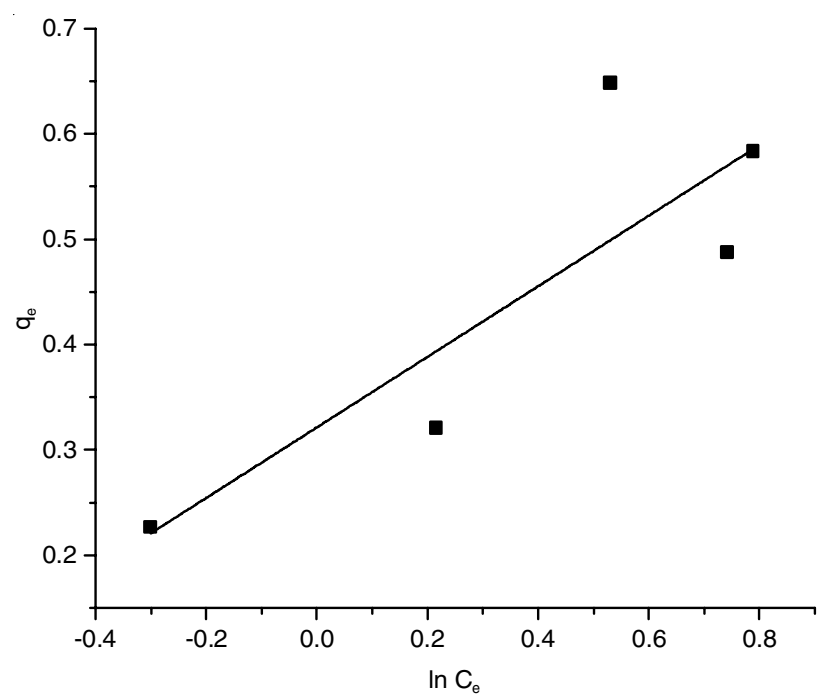

Fig. 10. Plot for Temkin isotherm for trichoderma plus biofertilizer

\begin{tabular}{clcc}
\multicolumn{5}{c}{ TABLE-2 } \\
\multicolumn{3}{c}{ STATISTICAL PARAMETERS AND LANGMUIR, } \\
\multicolumn{2}{c}{ FREUNDLICH AND TEMKIN ISOTHERM COEFFICIENTS } \\
\hline \multirow{2}{*}{ Isotherm } & \multicolumn{1}{c}{ Parameter } & Value & $\begin{array}{c}\text { Correlation } \\
\text { coefficient }\end{array}$ \\
\hline \multirow{2}{*}{ Langmuir } & $\mathrm{Q}_{\mathrm{m}}(\mathrm{mg} / \mathrm{g})$ & 1.623 & 0.563 \\
& $\mathrm{~K}_{\mathrm{a}}(\mathrm{L} / \mathrm{mg})$ & 0.951 & 0.966 \\
\hline \multirow{2}{*}{ Freundlich } & $\mathrm{n}(\mathrm{g} / \mathrm{L})$ & 1.319 & 0.950 \\
& $\mathrm{k}_{\mathrm{f}}(\mathrm{L} / \mathrm{mg})$ & 0.950 & 0.725 \\
\hline \multirow{2}{*}{ Temkin } & $\mathrm{B} 1(\mathrm{mg} / \mathrm{g})$ & 0.307 & \\
& $\mathrm{~A}(\mathrm{~L} / \mathrm{mg})$ & 11.70 &
\end{tabular}

\section{Kinetic study}

Pseudo first and pseudo second order: The rate and adsorption process mechanism can be investigated with kinetic study. The results of adsorption of rhodamine $B$ dye by biofertilizer containing Trichoderma viride showed that with time and speed of agitation, the adsorption rate of the dye molecules increased as agitation time was increased. To determine the mass transfer and rate controlling mechanism, experimental data of kinetics were correlated to linear relation of the pseudo first and pseudo second order models as represented by eqns. 5 and 6 , respectively.

$$
\log \left(\mathrm{q}_{\mathrm{e}}-\mathrm{q}_{\mathrm{t}}\right)=\log \mathrm{q}_{\mathrm{e}}-\frac{\mathrm{k}_{1} \mathrm{t}}{2.303}
$$

where $\mathrm{q}_{\mathrm{e}}$ is the equilibrium concentration and $\mathrm{q}_{\mathrm{t}}$ is the dye concentration at time $\mathrm{t} ; \mathrm{k}_{1}(\mathrm{~min})^{-1}$ and $\mathrm{k}_{2}(\mathrm{~g} / \mathrm{mg} \min )$ are the pseudo first and second order rate constant, respectively. If the process of adsorption follows kinetics of first order the plot of $\ln \left(\mathrm{q}_{\mathrm{e}}-\mathrm{q}_{\mathrm{t}}\right)$ versus contact time $(\mathrm{t})$ gives a straight line. The $\mathrm{k}_{1}$ value are obtained from plot of $\ln \left(\mathrm{q}_{\mathrm{e}}-\mathrm{q}_{\mathrm{t}}\right)$ versus $\mathrm{t}$, for the rhodamine B dye adsorption on biofertilizer containing Trichoderma viride as adsorbent are tabulated in Table- 3 . The values of $\mathrm{q}_{\mathrm{e}}$ obtained from plot of Lagergren are near to the values of $\mathrm{q}_{\mathrm{e}}$ obtained.

The pseudo second order model is represented as:

$$
\frac{\mathrm{dq}_{\mathrm{t}}}{\mathrm{dt}}=\mathrm{k}_{2}\left(\mathrm{q}_{\mathrm{e}}-\mathrm{q}_{\mathrm{t}}\right)^{2}
$$

where $\mathrm{k}_{2}(\mathrm{~g} / \mathrm{mg} \mathrm{min})$ is rate constant of pseudo second order model. A linear plot of $\mathrm{t} / \mathrm{q}_{\mathrm{t}}$ versus $\mathrm{t}$ would confirm the applicability to the process. Therefore, the process of sorption can be more appropriate by kinetic model of pseudo second order than pseudo first order for biofertilizer containing Trichoderma viride.

Intraparticle diffusion: The most common adsorption process well-designed relationship is that the uptake of dye molecules varies proportionally with square root of time as represented by eqn. 7 .

$$
\mathrm{q}_{\mathrm{t}}=\mathrm{k}_{\mathrm{id}} \mathrm{t}_{1 / 2}+\mathrm{C}
$$

where $\mathrm{k}_{\mathrm{id}}$ is the rate constant of intraparticle diffusion. The intercept values $(\mathrm{C})$ gives the boundary layer thickness idea i.e., greater the value of intercept larger the effect of boundary layer. This gives the idea about rapid exploitation of adsorbing sites on the surface of the adsorbent. The $\mathrm{k}_{\mathrm{id}}$ is the value of slope and $\mathrm{C}$ is the value of intercept was obtained from the linear plot as shown in Fig. 11.

Elovich model: The Elovich equation is described as follows:

$$
\mathrm{q}_{\mathrm{t}}=\frac{1}{\mathrm{~b}} \ln (\mathrm{ab})+\frac{1}{\mathrm{~b}} \ln \mathrm{t}
$$

where $\mathrm{a}$ and $\mathrm{b}$ are constants. The constant value $\mathrm{a}$ is referred as the initial sorption rate and $b$ value is referred to the surface coverage and activation energy extent for chemisorption. The constant $\mathrm{a}$ and $\mathrm{b}$ values are obtained from the linear graph of $\mathrm{q}_{\mathrm{t}}$ versus $\ln \mathrm{t}$ (Fig. 12).

Film diffusion model: During the excitation of rhodamine B dye molecules between liquid phase and solid phase, the boundary layer plays an important role in adsorption process. The equation of liquid diffusion model is given as below:

TABLE-3

ADSORPTION SUMMARY FOR TRICHODERMA PLUS BIOFERTILIZER

\begin{tabular}{ccc|cc|cc|cc|cc}
\hline \multirow{2}{*}{$\begin{array}{c}\text { Initial } \\
\begin{array}{c}\text { concentration } \\
\text { of dye } \\
(\mathrm{mg} / \mathrm{L})\end{array}\end{array}$} & \multicolumn{2}{c|}{\begin{tabular}{c} 
Intra particle diffusion \\
\cline { 2 - 11 }
\end{tabular}} & \multicolumn{2}{c|}{$\begin{array}{c}\text { Pseudo first order } \\
\text { constant }\end{array}$} & $\mathrm{R}^{2}$ & $\begin{array}{c}\text { Rate } \\
\text { constant }\end{array}$ & $\mathrm{R}^{2}$ & $\begin{array}{c}\text { Pseudo second order } \\
\text { model } \\
\text { constant }\end{array}$ & $\mathrm{R}^{2}$ & \multicolumn{2}{|c|}{$\begin{array}{c}\text { Rate } \\
\text { constant }\end{array}$} & $\mathrm{R}^{2}$ & $\begin{array}{c}\text { Rate } \\
\text { constant }\end{array}$ & $\mathrm{R}^{2}$ \\
\hline 7 & 0.0114 & 0.951 & 0.0229 & 0.934 & 5.35 & 0.991 & 0.0469 & 0.935 & 0.0238 & 0.906 \\
10 & 0.0197 & 0.912 & 0.0114 & 0.815 & 3.35 & 0.813 & 0.078 & 0.829 & 0.0144 & 0.815 \\
15 & 0.0289 & 0.821 & 0.0362 & 0.967 & 0.067 & 0.989 & 0.0125 & 0.888 & 0.0347 & 0.927 \\
18 & 0.0301 & 0.857 & 0.0134 & 0.511 & 0.064 & 0.995 & 0.129 & 0.910 & 0.0358 & 0.421 \\
20 & 0.061 & 0.768 & 0.0461 & 0.804 & 0.013 & 0.803 & 0.225 & 0.776 & 0.0376 & 0.615 \\
\hline
\end{tabular}




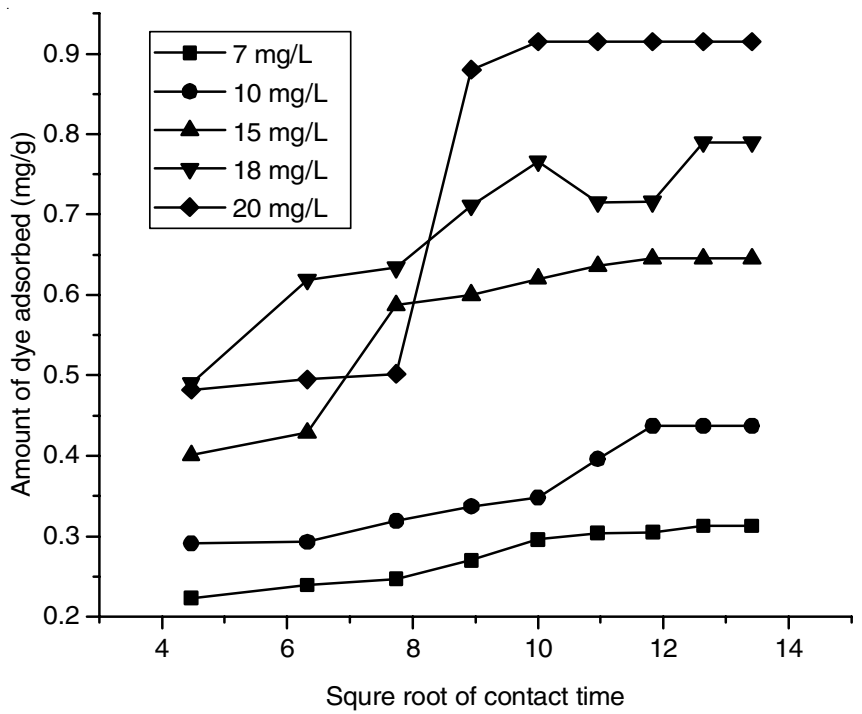

Fig. 11. Intraparticle diffusion model for trichoderma biofertilizer

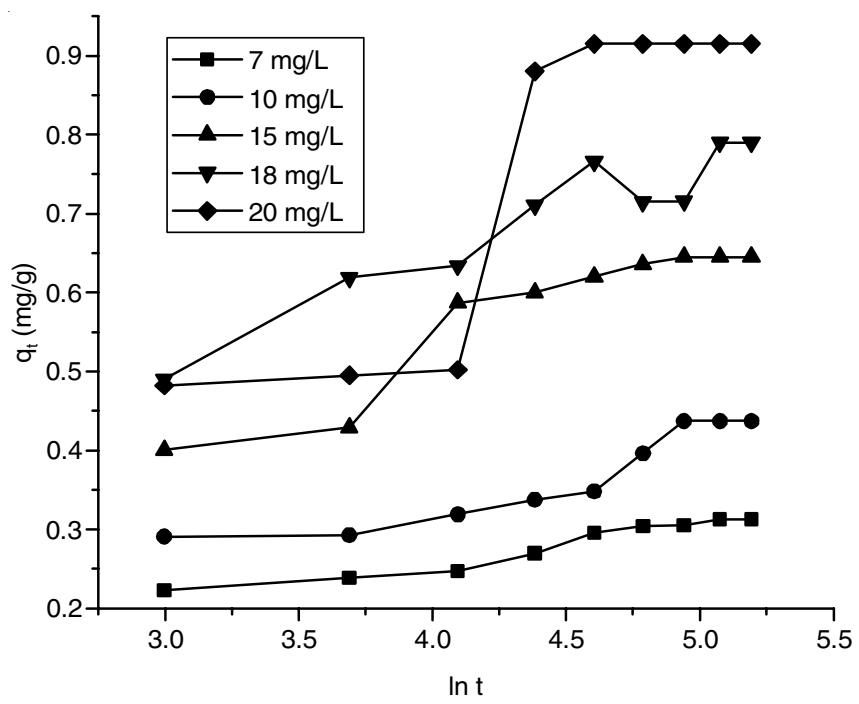

Fig. 12. Elovich model for trichoderma biofertilizer

$$
\ln \left(1-\frac{1-\mathrm{q}_{\mathrm{t}}}{\mathrm{q}_{\mathrm{e}}}\right)=\mathrm{k}_{\mathrm{fd}} \mathrm{t}
$$

where $\mathrm{q}_{\mathrm{t}} / \mathrm{q}_{\mathrm{e}}=\mathrm{F}$ gives the fractional attainment of equilibrium, and $k_{i d}$ is the rate constant of film diffusion. Plot of $-\ln (1-F)$ versus $\mathrm{t}$ showed a straight line in which $\mathrm{k}_{\mathrm{id}}$ equal to slope gave an idea that rhodamine B dye adsorption was controlled by liquid film diffusion surrounding by the surface of solid adsorbent. The $\mathrm{k}_{\mathrm{id}}$ values and correlation coefficient of adsorbent are listed in Table-3.

Reproducibility and reuse: To achieve the environmental sustainability for the current bioadsorbent, a high reproducibility would add important feature towards the treatment of water. For this three number of cycles of adsorption-desorption experiments were carried out at optimized parameters. During the first cycle, rhe removal rate of dye was $76 \%$ was acheived. After first cycle, capacity of adsorption of rhodamine B dye decreased by $12 \%$ because of incomplete desorption of rhodamine B dye. In adsorption-desorption cycles after three cycles over $49 \%$ recovery ratio was achieved, indicating the good reproducible capacity of biofertilizer containing Trichoderma viride as bioadsorbent (Fig. 13).

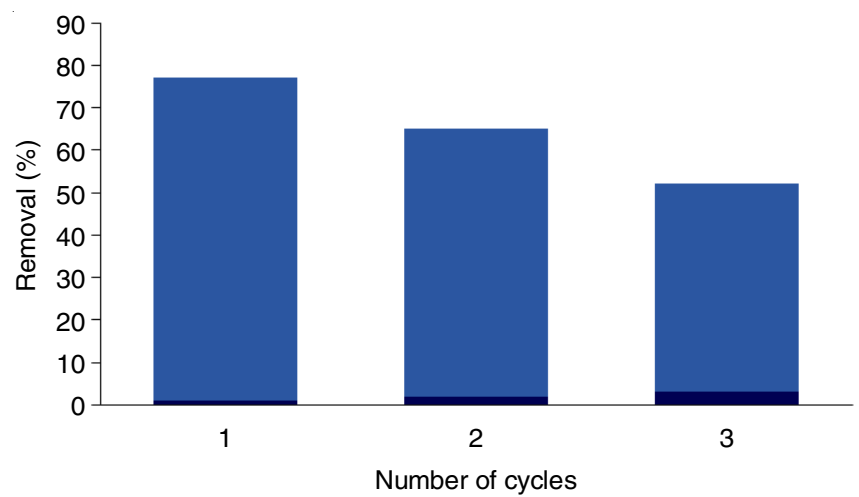

Fig. 13. Percentage removal of dye in reproducing trichoderma plus biofertilizer

Comparison with other reported adsorbents: A comparison of the maximum removal capacity of biofertilizer containing Trichoderma viride with other low cost adsorbents is shown in Table-4. The biofertilizer containing Trichoderma viride shows higher adsorption capacity of adsorption for rhodamine B dye with respect to other adsorbents. Therefore, biofertilizer containing Trichoderma viride is much better and efficient bioadsorbent for the elimination of rhodamine B dye from aqueous solution.

\begin{tabular}{lcc}
\multicolumn{3}{c}{ TABLE-4 } \\
\multicolumn{3}{c}{ COMPARISON OF THE REMOVAL CAPACITY } \\
BY OTHER LOW COST ADSORBENTS \\
\hline \multicolumn{1}{c}{ Adsorbent } & $\begin{array}{c}\text { Maximum } \\
\text { removal }\end{array}$ & Ref. \\
\hline Animal bone meal & 64.95 & {$[18]$} \\
Magnifera indica leaf powder & 77.00 & {$[19]$} \\
Calcined mussel shells & 45.67 & {$[20]$} \\
Casuarina equisetifolia cone & 49.50 & {$[21]$} \\
Trichoderma plus biofertilizer & 76.00 & This study \\
\hline
\end{tabular}

\section{Conclusion}

The adsorption process of rhodamine B dye using low cost biofertilizer containing Trichoderma viride as bioadsorbent was studied at optimized parameters. The maximum elimination of rhodamine B dye $(76 \%)$ was achieved at 50 ${ }^{\circ} \mathrm{C}$. The kinetic data was suitable for pseudo second order for the bioadsorbent and the Freundlich isotherm showed a good fit for kinetic data of process of adsorption.

\section{CONFLICT OF INTEREST}

The authors declare that there is no conflict of interests regarding the publication of this article.

\section{REFERENCES}

1. S.P. Kamble, P. Dixit, S.S. Rayalu and N.K. Labhsetwar, Desalination, 249, 687 (2009); https://doi.org/10.1016/j.desal.2009.01.031.

2. K. Shen and M.A. Gondal, J. Saudi Chem. Soc., 21, S120 (2017); https://doi.org/10.1016/j.jscs.2013.11.005.

3. E. Baldev, D.M. Ali, A. Ilavarasi, D. Pandiaraj, K.A.S.S. Ishack and N.Thajuddin, Colloids Surf. B: Biointerfaces, 105, 207 (2013); https://doi.org/10.1016/j.colsurfb.2013.01.008. 
4. N.D. Mathur and S.R. Shukla, Indian J. Chem. Technol., 25, 315 (2018).

5. C. Namasivayam and D. Kavitha, Dyes Pigments, 54, 47 (2002); https://doi.org/10.1016/S0143-7208(02)00025-6.

6. G.C. Panda, S.K. Das and A.K. Guha, J. Hazard. Mater., 164, 374 (2009); https://doi.org/10.1016/j.jhazmat.2008.08.015.

7. C. Namasivayam, N. Muniasamy, K. Gayatri, K. Ranganathan and M. Rani, Bioresour. Technol., 57, 37 (1996); https://doi.org/10.1016/0960-8524(96)00044-2.

8. P.P. Selvam, S. Preethi, P. Basakaralingam, N.Thinakaran, A. Sivasamy and S. Sivanesan, J. Hazard. Mater., 155, 39 (2008); https://doi.org/10.1016/i.jhazmat.2007.11.025.

9. H.B. Senturk, D. Ozdes and C. Duran, Desalination, 252, 81 (2010); https://doi.org/10.1016/j.desal.2009.10.021.

10. R.S. Annadurai, R. Juang and D. Lee, J. Hazard. Mater, 92, 263 (2002); https://doi.org/10.1016/S0304-3894(02)00017-1.

11. M. El-Haddad, R. Mamouni, N. Saffaj and S. Lazar, J. Saudi Chem. Soc., 20, S53 (2016); https://doi.org/10.1016/j.jscs.2012.08.005.

12. K.A. Adegoke and O.S. Bello, Water Resour. Ind., 12, 8 (2015); https://doi.org/10.1016/j.wri.2015.09.002.

13. L. Peng, P. Qin, M. Lei, Q. Zeng, H. Song, J. Yang, J. Shao, B. Liao and J. Gu, J. Hazard. Mater., 209-210, 193 (2012); https://doi.org/10.1016/j.jhazmat.2012.01.011.
14. J.S. Cao, J.X. Lin, F. Fang, M.T. Zhang and Z.R. Hu, Bioresour. Technol., 163, 199 (2014); https://doi.org/10.1016/j.biortech.2014.04.046.

15. E.A. Pirbazari, E. Saberikhah, M. Badrouh and M.S. Emami, Water Resour. Ind., 6, 64 (2014); https://doi.org/10.1016/j.wri.2014.07.003.

16. S. Ramuthai, V. Nandhakumar, M. Thiruchelvi, S. Arivoli and V. Vijayakumarn, E-J. Chem., 6(S1), 5363 (2009); https://doi.org/10.1155/2009/470704.

17. K. Kulkarni, G.M. Bhogale and R. Nalawade, Korean J. Chem. Eng., 35, 153 (2018); https://doi.org/10.1007/s11814-017-0254-3.

18. M. El-Haddad, R. Mamouni, N. Saffaj and S. Lazar, J. Saudi Chem. Soc., 20(S1), S53 (2016); https://doi.org/10.1016/j.jscs.2012.08.005.

19. A.T. Khan, S. Sharma and I. Ali, J. Toxicol. Environ. Health Sci., 3, 286 (2011).

20. M. El-Haddad, A. Regti, M.R. Laamari, R. Slimani, R. Mamouni, S. ElAntri and S. Lazar, J. Taiwan Inst. Chem. Eng., 45, 533 (2014); https://doi.org/10.1016/i.jtice.2013.05.002.

21. M.K. Dahri, M.R.R. Kooh and L.B.L. Lim, Adv. Phys. Chem., 2016, Article ID 9497378 (2016); https://doi.org/10.1155/2016/9497378. 